\title{
The articulation of beur female identity in the works of Farida Belghoul, Ferrudja Kessas and Soraya Nini
}

In view of the relatively recent literary success of works by secondgeneration Maghrebis born and brought up in France and the self-designatory origins of the term beur, ${ }^{1}$ this chapter examines the work of three beur women writers in order to establish the extent to which the highly specific socio-historical locus of the beur writer, when combined with her female subject position, may produce narrative similarities, whether formal or thematic. Beur literature only began to enjoy commercial success in the early 1980 s, when a substantial number of the children of North African immigrants first reached adulthood. The designation beur is considered an example of verlan - a form of French slang involving the inversion of syllables - stemming from the term 'Arabe'. The term itself has become problematic in that its common currency in France and appropriation by the French media have endowed it with many of the pejorative, Occidental associations of its precursor. Alternative modes of designation refer to the beur population as the offspring of North African immigrants or - since this is generally the case - as second-generation Algerians, alternatives which are not only rather cumbersome but inadequate in that they fail to acknowledge the specific problematics of the French locus these individuals inhabit. Therefore, this chapter will continue to employ the - at least succinct - term beur to refer to these writers who are the offspring of Algerian immigrants who came to France during the 1950 s and 1960 .

While seeking to identify some common ground in beur women's writing, this chapter does not wish to play down the variety and hybridity of beur narratives in a quasi-colonialist drive for uniformity and categorisation. Indeed, the very recentness of the emergence of this writing makes any 
endeavour to characterise its expression of identity politics tentative. Given the diversity of the writers who are conventionally grouped under the umbrella term beur - some writers classed as beur were born in North Africa then came to France, others were born in France of, say, a French mother and Algerian father - this chapter will focus on texts by writers who most closely conform to beur criteria, in that all three were born in France of Algerian parents. The works to be examined are Georgette! by Farida Belghoul, Beur's story by Ferrudja Kessas and Ils disent que je suis une beurette by Soraya Nini. ${ }^{2}$ These works are all autobiographical and are written by authors of working-class origin - which would seem to be an inevitable component of this particular permutation of 'Beurness', in that the firstgeneration Algerian parents of these writers came to France as unskilled workers. ${ }^{3}$ They are also the first publication of the writers in question, and, in two out of three cases, the only publication at the time of writing. Indeed, one 'extraneous' characteristic of the articulation of identity in beur writing is that many writers limit that articulation to one, generally autobiographical, work, continuing with their chosen profession after publication.

The autobiographical nature of much beur writing accounts for its commonly first-person narrative voice and oral expression, an expression which may encompass examples of verlan, English and Arabic terms, or regional and slang vocabulary - in other words, the polyphonic textual language mirrors the hybrid identity of the protagonists. The emphasis on orality in beur women's writing is particularly appropriate given the limited access of first-generation Algerian women to written language and the recentness of their daughters' own exposure to it in the form of French literature. If the 'orature' of texts by beur women writers reflects the urgency of the narrators' desire for self-expression, the incorporation of nonliterary language can also be read as a positive assertion of female otherness or as a form of protest, in that the perceived violence inflicted on the colonised economically and culturally is reciprocated linguistically - what Ketu H. Katrak, in describing the oral traditions of much post-colonial women's writing, refers to as 'effective tools of resistance against neocolonial tendencies and against women's particular oppressions'. ${ }^{4}$ However, as this chapter argues, the protagonists of Belghoul's, Kessas's and Nini's works also foreground the necessity of consciously assimilating the French language in both its oral and written forms - and the consequent importance of the education system - in articulating their cross-cultural position. The interdiction on uncensored female expression within the family home and the narrators' underconfidence in French outside it may also contribute to 
the need for a narrative outlet in which they are given a voice: unable to experience the freedom of their brothers and fathers, beur female protagonists are shown to experience it vicariously through the reading, and, subsequently, the writing of, narratives. In the dedication to Beur's story, Ferrudja Kessas makes the personal and political impetus behind the act of writing clear: 'Je dédie cette histoire à mes sœurs maghrébines pour que nous cessions d'être cette entité négligeable qui hante l'arrière-plan des romans de nos jeunes écrivains maghrébins' (I dedicate this story to my Maghrebi sisters so that we may stop being that negligible entity which haunts the background of the novels by our young Maghrebi [male] writers).

Kessas's reference to beur women's developmental anteriority to their male counterparts in literature may further account for the predominance of first-person autobiographical narratives in the texts examined, in that autobiography often provides narrative entry for marginalised groups misor non-represented by the dominant culture. It is perceived to constitute a means of countering the 'inauthentic' voices or forms of ventriloquism imposed by the dominant group on the subaltern. Two of the three texts are written in the first person, with only Beur's story written in the third person. While Kessas's work adopts a more 'classic' narrative approach, in which ambiguities in textual development are minimal, Georgette! is the most formally interesting of the works in that it combines a first-person narrative account - and one which, like Nini's and many other beur narratives, resembles a form of oral diarywriting - with a more inventive, quasifantastic narrative, in which the reader is frequently unsure whether the narrator is relating or imagining events. These tangential narrative meanderings follow the narrator's thought processes before returning to the 'real' present, meanderings which can partly be attributed to the age of the narrator - she is only 7 - and the consequently more permeable dividing line separating her worlds of fact and fiction, as well as to her desire to transgress the constrictive limits which circumscribe the locus of her identity. Indeed, this desire to avoid being easily categorised - and dismissed accounts for the common portrayal of beur female protagonists as social chameleons, assuming whatever façade is most appropriate to the particular circumstances or milieux they inhabit. ${ }^{5}$

In all three texts, the role played by the narrators' imagination or imaginative fantasies - what Nini's narrator Samia terms 'une échappatoire' ( $p$. 263) (an evasion/means of escape) - enables them to tolerate the experiential constraints of le vécu more easily. In Georgette!, these fantasies serve to 
nourish the narrator's self-perception in the face of the French education system's drive for homogeneity (as well as her family's religious strictures), whether the narrator imagines herself as an old man - indicative of her desire to be respected by the other, a situation denied her by her age, race and gender; a cat - which points to her continuing independence behind her apparently domesticated appearance; or an American Indian - the symbol of the colonised since time immemorial, and, for the narrator, of her internal resistance to French acculturation. If the Indian is to preserve his identity and culture, he must outmanœuvre the cowboy, and never allow his 'real' self to be exposed: 'La carte d'identité des indiens est un secret de guerre [...] Personne connaît la vraie figure des indiens. Encore heureux! Sinon, le cow-boy les massacre tous, un par un' (p. 72) (The identity card used by Indians is a battle secret [...] No one knows the true face of the Indians. Just as well! Otherwise the cowboy would massacre them all, one by one). The symbolic value with which the narrator accredits the Indian accounts for her refusal to watch the end of westerns on television; she endows the Indian with an immortality she does not wish to see contradicted by 'real-life' cultural representations of him. ${ }^{6}$

Georgette! has the shortest timespan of all the works: while the narrative covers a year, it focuses principally on twenty-four hours in the life of the protagonist. Ils disent que je suis une beurette relates the experiences of a 12-year-old girl, Samia, through until the age of 17, while Beur's story is set during the year of the baccalauréat for Malika. By their focus on the education system, all three texts point up the pivotal role played by the socialisation process and formation of identity in beur women's writing, as the narrators attempt to negotiate the influences of their French and Arabic cultures, cultures habitually portrayed as antithetical in their Occidental/Christian and Oriental/Muslim traditions. The problematic marriage of these two cultures in beur women's writing, paradoxically, may also account for its commercial success, in that the bi-cultural focus of these works serves to defamiliarise the familiar for the reader - in the case of French culture - and familiarise the unfamiliar, in the case of Algerian culture. ${ }^{7}$ These female protagonists inhabit the 'border zones' of culture, or what may be viewed as a form of Homi K. Bhabha's 'Third Space', a hybrid intermediacy characterised by the indefinite renegotiation of identity. ${ }^{8}$ If the temporal limits of the works are relatively tight - the texts are also written contemporaneously with events portrayed - all three take place within highly restricted spatial limits, restrictions closely linked to the gender of the protagonists. There is repeated mention of the interdictions 
forbidding beur girls to step beyond the experiential parameters allowed by the journey from home to school, and by their education itself. When not attending school, they are confined to the home - typically a highrise block of flats in a housing estate ${ }^{9}$ - and are shown to lead a claustrophobic existence utterly lacking in privacy which centres on the drudgery of housework rather than on the potentially dangerous intellectual stimulation provided by homework.

These romans d'apprentissage represent the daily voyage made by the protagonists between the Algerian domestic culture and the French educational one. The narrators inhabit a cross-cultural position, marginalised because of their racial origins in the French public domain and because of their gender within the Algerian domestic domain: if French society is shown to desire the eradication of all ambivalence and multiplicity in favour of a monolithic national identity, the Algerian family unit similarly seeks to isolate its female members from French paradigms of womanhood. In both Nini's and Kessas's works, there is little sense of racial solidarity within the family, in that male members mistreat and physically abuse their sisters. Even in Georgette!, the narrator's predominantly sympathetic father hits her mother when she dares to speak her mind. Whatever the racism they encounter in French society, Arabic men are shown to perpetuate that oppression within the domestic domain, to duplicate the discrimination they themselves experience. Indeed, in Beur's story, the protagonist Malika's more radical sister Fatima maintains that the form of racial 'emasculation' which forbids Arabic men to exert authority outside the home intensifies their need to do so inside it: 'Et puis, justement eux qui ont tant de problèmes, ils devraient nous comprendre, nous aussi nous sommes de la deuxième génération, un jour ou l'autre on sera peut-être confrontés à pire que ça! Et au lieu de nous donner la main, ils nous tournent le dos! Et faute de jouer les caïds dehors, ils les jouent chez eux!' (p. 202) (And precisely because they [Arabic men] have so many problems, they should understand our situation. We're also second-generation immigrants, and one day we may have to face an even worse predicament! And instead of offering us a helping hand, they turn their backs on us! Since they can't play the big shot outside, they do it at home!).

The fundamental role played by identity and naming - whether indicating ethnic or sexual identity - is made clear in the titles of the works. If Beur's story points to the representative value which the narrator attributes to her Bildung, Ils disent que je suis une beurette immediately signals the narrator's distancing from the nominal politics which seek to categorise her 
as beur, a distancing apparent in the narrator's desire for integration into French society at the text's conclusion. The deliberate fluidity of the designation 'ils' points to the female narrator's sense of dual oppression at the hands of both French and Algerian men. Georgette! further foregrounds the problematics of identity by employing a traditional French name in its title, a name the nameless protagonist imagines her father calling her, thereby highlighting her degree of alienation from her culture of origin, and her sense of betrayal following her assimilation by the French education system. The inherent falseness French identity represents for the young narrator is given symbolic resonance when she is asked by an old French woman to write letters to her pretending to be her sons, a request which further reinforces the eradication of the narrator's Arabic identity initiated by her school environment. ${ }^{10}$ The narrator draws attention to the significance the articulation of identity holds for her when she determines to teach her own mother to write her name as soon as she herself learns to write. As Kessas's dedication highlights, these daughters of first-generation Muslim women, women who are generally illiterate and unable to express themselves in French, seek to speak out against the tradition of silence in order to voice their own sense of identity and to legitimate their own life histories.

In all these texts, the female siblings are more educated and fare better at school than their brothers, due to their perception of education as empowering, as a means of extending the limited opportunities of their domestic culture, a perception surely intensified by the working-class origins of all three narrators. It is not surprising that constant exposure to the 'liberalising' individualism of Western values strikes a particularly resonant chord with beur adolescent girls on the threshhold of adulthood, an adulthood which their culture of origin typically represents as a diminishment of freedom and opportunities in the form of an arranged marriage, of being tied ever more firmly to the domestic. ${ }^{11}$ Education also provides the female protagonists with the linguistic fluency they require to act as gobetweens - as both cultural and linguistic interpreters - for their parents and French society. ${ }^{12}$ In Georgette!, the young narrator may dislike school and learning to read and write, yet continues with it in order to increase future professional opportunities: 'Pour l'instant,j'ai besoin d'apprendre à lire. C'est idiot de se presser et de se jeter sur un mauvais risque: je veux pas devenir clochard. Dès que je dessine une écriture magnifique, aussi belle que la voix de mon père, je m'en vais loin d'ici,je me sauve au ciel avec un bon métier' (p. 64) (For now, I need to learn to read. It doesn't make 
sense to rush things and to risk my future: I don't want to become a tramp. As soon as I can master beautiful handwriting, as beautiful as my father's voice, I'm going to leave all this far behind, the sky's the limit if I get a good job). Georgette!'s opening words which describe the end of a school break immediately signal the normative role played by the education system in teaching the protagonist French. An example of a verlan-type malapropism is swiftly replaced by its correct expression: 'La sonne cloche... Non, la cloche sonne' (p. 9) (The ring bells... no, the bell rings). The narrator has difficulty mastering spoken and written French, and this opening malapropism foreshadows a thematics in the work, in which her French schooling associates Arabism with being 'the wrong way round', as symbolised by her father's writing in her homework jotter at what is viewed as the back according to Western convention.

The narrator's acquisition of French language is the central thematics of Georgette!, and a principal subject in beur writing generally. References to pencils, pens and inkpots; to eyes (reading), hands and fingers (writing) and throats (speaking); and to the differences between Arabic and French modes of writing and reading abound in the work. It is perhaps unsurprising that the narrator's closest friend in Georgette! has a speech impediment, mirroring her own self-perceived difficulty in expressing herself. If the teacher is described as opening the narrator's book at the 'wrong' place towards the beginning of the work, the narrator's gradual assimilation of the values of French culture - or the efficaciousness of French 'internal colonialism' - is illustrated by her change in perspective when she later accuses her father of opening the book at the wrong place and dismisses his Arabic writing: 'Son écriture pourrie c'est des gribouillages. L'écriture à l'envers n'existe pas! En vérité, il sait pas écrire et il me raconte des histoires debout. Il est complètement marteau, ce bonhomme!' (p. 58) (His awful writing is nothing but scribbles. Back-to-front writing doesn't exist! If truth be told, he can't write and he tells me nonsense stories. He's completely nuts, this guy!). This dichotomised representation in which the culture of the father is set up against that of the female schoolteacher is also apparent in Ils disent que je suis une beurette. In this work, Arabic is the language of the father and of the male teachers, who, at her father's insistence, give Samia Arabic lessons, a language she cannot understand. It is French which produces an affective identification in the narrator, and which comes to be associated with the liberating feminine, both in the form of her schoolteacher Mme Sallibert, who provides Samia with a 'real-life' alternative female role model, and in the literature she recommends. As this 
chapter has suggested, literature is an important representative medium for the protagonists of these beur texts in that it allows them to experience vicarious liberation in the form of French protagonists, a paradigm of liberation their own texts implicitly hold out to other beur women readers. In all three texts, the narrators' gradual acculturation is reinforced by the role played by an older French woman who can be seen as partially usurping the Algerian maternal, whether Mme Sallibert in Ils disent que je suis une beurette, 'la vieille' in Georgette! who effectively asks the narrator to become her surrogate child, and both the bookshop owner Malika befriends in Beur's story and her schoolteacher, as an extract from one of her poems makes clear: 'Maîtresse, vous voulez bien être ma maman aussi/Ce sera facile, je vous aime déjà tant/Mais tant!' (p. 95) (Miss, can you be my mummy too/It would be easy, I love you so much already/So much!). ${ }^{13}$

In none of the works is the protagonist's bi-cultural identity experienced as plenitude or enriching hybridity, ${ }^{14}$ yet the degree of alienation varies from work to work with the most intense desire for integration expressed in Ils disent que je suis une beurette ${ }^{15}$ Samia offers the most condemnatory assessment of her Algerian heritage, yet, like Malika in Beur's story, acknowledges generational differences in attitude and the complex imbrication of her socialisation process and cross-cultural position. Malika attributes the rigidity of her parents' adherence to Algerian cultural beliefs to their need to have some sense of continuity in a society largely alien to them. All three narratives end on a note of loss or departure: Ils disent que je suis une beurette concludes with the departure of the protagonist for greater integration in French society and the (temporary?) abandonment of her endeavours to participate in the Algerian domain; in Beur's story, Malika's best friend and alter ego Farida is unable to accept the limitations of her role as an Arab woman and commits suicide. When Farida's ghost criticises Malika for her lack of intervention or action at the text's conclusion, the reader is clearly supposed to interpret this as a call for beur women to participate more fully in their fate. ${ }^{16}$ If a positive assumption of beur identity can be seen as embodied in Fatima, Malika's sister, who decides to inform her classmates about Arabic culture and Algerian traditions, and perhaps to write a book about her experiences, as well as in Malika's own intention to continue with her education, the narrative ends on a note of desolation when Malika learns of the death of her best friend. Georgette! ends with the departure of the protagonist in that the reader presumes she has died under the wheels of a car, although the absence of a full stop after the work's final sentence makes such a conclusion ambiguous. 
Ultimately, then, all three texts conclude by a form of inconclusiveness, a lack of resolution reflected in the uncertain sense of self experienced by their beur protagonists in contemporary France, and in the girls' status as cultural nomads never fully assimilated by either Algerian or French culture.

As a peripheral group within a peripheral group, beur women writers have the particularly acute sense of the split self or dual identity that W. E. B. Du Bois attributes to the African American, whose self-perception, he argues, is intrinsically linked to the other's perception of him, resulting in a form of 'double consciousness' or awareness. ${ }^{17}$ This awareness is positively channelled in Ils disent que je suis une beurette, in which the narrator develops from being the perceived, objectified other in a television documentary about her housing estate to locating herself as perceiving subject of her own literary histoire (story/history). The previously subaltern position is abandoned thanks to the empowering mimicry of the coloniser's gaze, which, to quote Bhabha, may be seen as constituting one of several 'strategies of subversion that turn the gaze of the discriminated back upon the eye of power'. ${ }^{18}$ Much beur women's writing demonstrates that texts which portray the unfamiliar subject of bi-cultural female identity within a more classic narrative framework (and thereby implicate an extensive readership) provide effective vehicles for the deconstruction of the racial and sexual selves imposed upon their female narrators in contemporary French society. As Martine Delvaux remarks:

Le mimétisme, en ce qu'il constitue une représentation de soi-même qui récupère partiellement mais suffisament l'autre qui menace et ainsi l'encourage à se reconnaître en celui qu'il domine, permet l'articulation d'un tiers espace qui constitue le lieu d'une manipulation de l'organe de domination.

(Mimicry, insofar as it constitutes a form of self-representation which partially yet sufficiently harnesses the threatening other, and therefore encourages him to perceive himself in the person he dominates, allows for the articulation of a third space which constitutes the place of manipulation of the organ of domination. $)^{19}$

As intrinsically fluid, non-specular mirrors of the post-colonial white, middle-class, 'indigenous' French male subject position, the works examined in this chapter give voice to the previously unauthorised through their exploration of the complexities of beur female identity. At this particular socio-historical juncture, narratives by beur women can be seen to occupy 
a 'third space', a space which, if not yet characterised by a nourishing transcultural reciprocity, none the less represents a form of liberation: having long had their identities contained in ideological straitjackets, the female narrators in these examples of beur women's writing signal the importance of finding their own voie/voix (way/voice) for future representation.

\section{Notes}

1 It is generally accepted that the term beur was first employed in the 1980 s by French-born children of North African immigrants living in Paris as a means of self-designation in order to escape the increasingly racist connotations of 'arabe'.

2 Farida Belghoul, Georgette! (Paris: Bernard Barrault, 1986); Ferrudja Kessas, Beur's story (Paris: L'Harmattan, 1990); Soraya Nini, Ils disent que je suis une beurette (Paris: Fixot 1993). Georgette! has been included in this study of beur women's writing since, while published in 1986, it remains one of the better-known beur texts. In view of the recent origins of beur writing, it would appear somewhat arbitrary to exclude a text from the mid-1980s when seeking to establish common narrative tendencies.

3 While literary criticism of beur works tends to focus on issues relating to race or gender, the role of class, or the interface between class and race in beur writing, has received relatively little critical attention, in spite of - or perhaps because of its ubiquity in the texts.

4 Ketu H. Katrak, 'Decolonizing culture: toward a theory for postcolonial women's texts', Modern Fiction Studies, 35(1) (1989), 157-79 (178).

5 One example of this inventiveness is the works' repeated references to the protagonists' need for an endless supply of alibis if they are to achieve acceptance at school through their participation in extra-curricular activities. A common pretext given to parents is that the narrators require time to study in the library, which may further account for the significant role played by literature in their lives.

6 This analogy between the French/cowboys and the Algerians/Indians is also made in Ils disent que je suis une beurette, when the narrator compares her two Algerian aunts to Indians and gives them Indian names, Geronimo and Conchise. In Beur's story, the family also watches westerns, films which, whatever their colonialist attitudes, reinforce traditional masculine values and are deemed relatively free from corrupting Western mores.

7 The role of readers and their implied characterisation in these works is an ambivalent one. While a section of the implied readership is clearly beur, these works target a predominantly French audience, in that they provide explanations of Arabic terms and aspects of Arabic culture. This is particularly true of Beur's story, which includes footnotes informing the reader of the meaning and pronunciation of certain Arabic words.

8 'Border zones' is a term employed by Renato Rosaldo in his article 'Ideology, place, and people without culture', Cultural Anthropology, 3 (1988), 77-87 (85). In 
his essay, 'The commitment to theory', in The Location of Culture (London and New York: Routledge, 1994), Homi K. Bhabha describes the benefits of a dynamic and enrichingly heterogeneous co-existence between politics and theory, or between different models of cultural identity, a 'Third Space' of ongoing negotiation.

9 Zola is probably the most frequently cited author in the texts of beur writers and the many descriptions of these highrise blocks in beur writing bring to mind the tenement block described in Zola's L'Assommoir, in that, like the latter, they are portrayed as self-contained (Algerian) villages.

10 The narrator's identity is literally eradicated by a representative of the French education system at the work's conclusion, when the reader is led to presume that the young narrator has been knocked down by a car driven by her teacher.

11 While some beur female narrators may highlight negative familial traits in order to justify their desire for integration into French society or, at the very least, to explain their vociferous criticism of the Algerian domestic domain, the quasistereotypical representation of the Arabic family in many beur texts may equally indicate these women writers' internalisation of the racist paradigms of French society.

12 The original title of Nini's text - L'Entre-deux - while foregrounding the cultural no man's land many beur individuals feel they inhabit, points to this role played by the children of Maghrebi immigrants.

13 If the mother figure in Beur's story is portrayed as cruelly conventional towards her daughters in her adherence to Arabic norms, she is something of a cypher in Ils disent que je suis une beurette - which can be interpreted as reflecting her submissiveness within the family unit - while in Georgette!, as in all the works, the mother's preference is clearly for her male children.

14 So pronounced is that bi-cultural identity in Georgette! that Michèle Bacholle in Un passé contraignant: double bind et transculturation (Amsterdam and Atlanta GA: Rodopi, 2000) perceives it as a form of schizophrenia.

15 It could, of course, be argued that Samia's integration into mainstream French society necessitates an inevitable broadening of the notion of Frenchness, and is therefore less politically pessimistic than it may first appear. Françoise Lionnet remarks that 'subaltern elements contribute to the evolution and transformation of the hegemonic system by producing resistances and counterdiscourses' ("Logiques métisses", cultural appropriation and postcolonial representations', in Mary Jean Matthews Green (ed.), Postcolonial Subjects, Francophone Women Writers (Minneapolis and London: University of Minnesota Press, 1996), pp. 321-43 (p. 323)). Given that such a process is not unidirectional, Lionnet prefers the term 'transculturation' to 'acculturation'. The reciprocity and deconstruction of simplistic binary oppositions inherent in this concept has echoes of Bhabha's 'Third Space'.

16 This projected politicisation of the beur female reader can be seen as reflecting two of the three characteristics of minority literature posited by Gilles Deleuze and Félix Guattari in Kafka: pour une littérature mineure (Paris: Minuit, 1975); in other words, 'le branchement de l'individuel sur l'immédiat-politique, l'agence- 
ment collectif d'énonciation' (p. 33) ('the connection of the individual to a political immediacy, and the collective assemblage of enunciation' (Kafka: Toward a Minor Literature, trans. Dana Polan (Minneapolis and London: University of Minnesota Press, 1986), p. 18)). The third characteristic, 'la déterritorialisation de la langue' (p. 33) ('the deterritorialisation of language' (p. 18)) is apparent in the linguistic polyphony already mentioned.

17 See William Edward Burghardt Du Bois, The Souls of Black Folk, ed. Henry Louis Gates Jnr and Terri Hume Oliver (New York and London: W. W. Norton, 1999). Susan Ireland's article 'Writing at the crossroads: cultural conflict in the work of beur women writers' first drew my attention to the relevance of Du Bois's work, and provided an invaluable introduction to many of the main concerns of beur women's writing generally. See French Review, 68(6) (May 1995), 1022-34.

18 Homi K. Bhabha, 'Signs taken for wonders', in The Location of Culture (London: Routledge, 1994), p. 112.

19 Martine Delvaux, 'L'ironie du sort: le tiers espace de la littérature beure', French Review, 68(4) (March 1995), 681-93 (688). The 'tiers espace' in Georgette! can also be seen as reflected in the tripartite structure of the work, in which, in Part 1 the narrator is most influenced by her home environment, in Part 2 by her school, and in Part 3 plays truant, inhabiting a type of no man's land both geographically and psychologically. 